\title{
JEKK
}

Jurnal Epidemiologi Kesehatan Komunitas

3 (2), 2018, 90-100

\section{Berbagai Faktor Risiko Kejadian Bayi Berat Lahir Rendah (BBLR) (Studi di Beberapa Puskesmas Kota Makassar)}

\author{
Hasriyani ${ }^{*}$, Suharyo Hadisaputro ${ }^{* *}$, Kamilah Budhi ${ }^{* * *}$, Mexitalia Setiawati ${ }^{* * *}$, Henry Setyawan ${ }^{* * *}$ \\ "Puskesmas Barombong, " Politeknik Kesehatan Semarang, ${ }^{* * *}$ Fakultas Kedokteran Undip, ${ }^{* * * * *}$ Fakultas \\ Kesehatan Masyarakat Undip
}

\begin{abstract}
Background: Low-birth-weight (LBW) as community health problem have remained as the main cause of prenatal morbidity and mortality. In Indonesia, the occurrence rate of LBW has reached $10,2 \%$. LBW has caused by multifactors such as maternal factor, fetus factor, and environmental factor. The aim of the study was to elaborate if maternal factor and environmental factor are the risk factors contributing to LBW occurrence.

Method: The study was based on case control design. The number of samples was 138 respondents who were categorized into 69 cases and 69 controls fulfilling the criteria of inclusion and exclusion. The cases were mothers with babies having birth weight $<2500$ grams regarding the gestational age, and the controls were mothers with babies having birth weight $\geq 2500$ grams regarding the gestational age. Sampling method to the cases was conducted by consecutive sampling while sampling to the controls was conducted by simple random sampling with matching to sex and location.

Results: Maternal factors observed as risk factors contributing to LBW are low nutritional status $(\mathrm{OR}=5.357 ; 95 \% \mathrm{CI}=1.985-14.457)$, illness pregnancy $(\mathrm{OR}=3.976 ; 95 \% \mathrm{CI}=1.669-9.476)$. Maternal factors and environmental factors observed as non-risk factors to LBWN are age $<20$ years old or age $>35$ years, the spacing of pregnancy $<2$ years, the of family members smoking at home, the of a food taboos culture, ANC status $<4 \mathrm{x}$, low social economy status.

Conclusion: Low nutritional status, illness pregnancy are risk factors contributing to LBW occurrence. The probability of LBW occurrence when those risk factors observed are $68,87 \%$.
\end{abstract}

Keywords : Low-birth-weight newborns; risk factors; nutritional status; illness pregnancy

*Penulis korespondensi : anihat1970@gmail.com 


\section{Pendahuluan}

Bayi lahir rendah (BBLR) di defenisikan sebagai bayi yang lahir dengan berat $<2500$ gram. ${ }^{1,2}$ BBLR merupakan masalah kesehatan masyarakat baik jangka pendek maupun jangka panjang, dan masih merupakan penyebab utama morbiditas dan mortalitas perinatal. ${ }^{1,3,4}$ Kejadian BBLR menurut WHO adalah $15,5 \%$ dari 20 juta kelahiran hidup pertahun, $96,5 \%$ berada di negara sedang berkembang dan dan memberikan konstribusi $60 \%-80 \%$ dari semua kematian neonatal. ${ }^{5-7}$

Tahun 2012, Angka Kematian Bayi (AKB) sebesar 32 kematian per 1000 kelahiran hidup, dan Angka Kematian Neonatus (AKN) sebesar 19 per 1000 kelahiran hidup angka yang sama dengan tahun 2007. Perhatian terhadap upaya penurunan $\mathrm{AKN}$ (0-28 hari) menjadi penting karena kematian neonatal memberi kontribusi terhadap $56 \%$ kematian bayi. ${ }^{8}$ Kejadian BBLR tahun 2013 sebesar 10,2\%. Angka tersebut mengalami penurunan jika dibandingkan dengan angka tahun 2010, yaitu sebesar $11,1 \%{ }^{9}$

Provinsi Sulawesi Selatan, merupakan salah satu provinsi yang mempunyai persentase BBLR urutan ke 7 tertinggi $(12.4 \%) .{ }^{10}$ Tahun 2013 (3,18\%) kematian bayi 7.22 per 1.000 kelahiran hidup, tahun 2014 (2,94\%) kematian bayi 7.23 per 1.000 kelahiran hidup, dan tahun 2015 (3,88\%) kematian bayi 7,58 per 1000 kelahiran hidup. ${ }^{11}$ Kejadian BBLR di Kota Makassar tahun 2014 sebesar $2.80 \%$, kematian $2.46 \%$, tahun 2015 sebesar $2.62 \%$ kematian $1.96 \%$, dan tahun 2016 kejadian BBLR sebesar (3,29\%). Dari 46 Puskesmas di Kota Makassar teradapat 6 Puskesmas dengan Persentase BBLR tertinggi yaitu Puskesmas Antang sebesar $11.13 \%$, Puskesmas Tamangapa sebesar $10.47 \%$, Puskesmas Kaluku Bodoa sebesar 9.46\%, Puskesmas Minasa Upa sebesar 8.64\%, Puskesmas Rappokalling sebesar 7.44\%, dan Puskesmas Pattingalloang sebesar $7.24 \%{ }^{12}$

Masalah yang terjadi pada BBLR adalah gangguan sistem pernafasan, susunan saraf pusat, kardiovaskular, hematologi, gastrointestinal, ginjal, termoregulasi diabetes melitus, penurunankecerdasan, gangguan tumbuh kembang fisik dan mental serta dapat menyebabkan kematian selama kanak-kanak. ${ }^{1,4,5,8,13}$

BBLR merupakan hasil interaksi berbagai faktor risiko yaitu faktor ibu (usia ibu, tingkat pendidikan, stres psikologis, status sosial ekonomi, ANC, paritas, jarak kehamilan, status gizi, asupan gizi, komsusmsi alkohol, penyakit kehamilan seperti anemia, hipertensi, pre eklampsi/eklampsia, hipermesis).Faktor lingkungan (keterpaparan asap rokok, budaya, tempat tinggal dataran tinggi, paparan zat beracun)..$^{3-414-15}$ Kota Makassar merupakan salah satu daerah dengan tingkat kejadian BBLR tertinggi diantara 24 Kabupaten/Kota di Sulawesi Selatan $(2,48 \%) .{ }^{11}$ Berdasarkan penjelasan dan uraian diatas peneliti tertarik untuk meneliti lebih lanjut mengenai faktor risiko kejadian BBLR tanpa memandang umur kehamilan di Kota Makassar.

\section{Metode}

Jenis penelitian ini adalah observasional analitik dengan desain case control dilengkapi analisis kualitiatif dengan indepth interview menggunakan kuesioner terbuka yang bertujuan untuk menjelaskan berbagai faktor risiko terhadap kejadian BBLR. Populasi studi kelompok kasus penelitian ini adalah semua ibu dengan bayi lahir berat $<2500$ gram di Puskesmas Antang, Puskesmas Tamangapa, Puskesmas Kaluku Bodoa, Puskesmas Minasa Upa, Puskesmas Rappokaling, Puskesmas Pattingalloang Kota Makassar yang tercatat di buku register kohor ibu dan/ atau buku register nifas tahun 2016/2017. Sedangkan populasi studi kelompok kontrol adalah semua ibu dengan bayi lahir berat $\geq 2500$ gram di Puskesmas Antang, Puskesmas Tamangapa, Puskesmas Kaluku Bodoa, Puskesmas Minasa Upa, Puskesmas Rappokaling, Puskesmas Pattingalloang Kota Makassar yang tercatat di buku register kohor ibu dan/ atau buku register nifas tahun $2016 / 2017$. Sedangkan populasi studi kelompok kontrol adalah semua ibu dengan bayi lahir berat $\geq 2500$ gram di Puskesmas 
Antang, Puskesmas Tamangapa, Puskesmas Kaluku Bodoa, Puskesmas Minasa Upa, Puskesmas Rappokaling, Puskesmas Pattingalloang Kota Makassar yang tercatat di buku register kohor ibu dan/ atau buku register nifas tahun 2016/2017.

Pengambilan sampel kasus secara consecutive sampling dan kontrol secara simple radom sampling. Variabel bebas dalam penelitian ini yaitu usia $\mathrm{ibu}<20$ tahun atau $>35$ tahun, status gizi kurang, adanya penyakit kehamilan, jarak kehamilan $<2$ tahun, adanya anggota keluarga merokok dalam rumah, adanya budaya pantangan makanan tertentu (cumi-cumi, udang, kepiting, ikan pari, daun kelor, durian, dan nanas), status ANC $<4 \mathrm{x}$, dan status sosial ekonomi rendah, sedangkan variabel terikat yaitu kejadian BBLR. Variabel confounding adalah tingkat pendidikan ibu dan paritas. Analisis data yang dilakukan pada penelitian ini berupa analisis univariat, bivariat dan multivariat pada tingkat signifikansi $p=<0.05$. Penelitian ini telah mendapat persetujuan etik penelitian dari Komisi Etik Penelitian Kesehatan (KEPK) FK 361/EC/FK-RSDK/VI/2017.

\section{Hasil}

Distribusi usia ibu pada kelompok kasus terbanyak pada kelompok usia 24-27 tahun $(30,4 \%)$, sedangkan pada kelompok kontrol terbanyak pada kelompok usia 24-27 tahun $(23.1 \%)$. Karakteristik responden secara lengkap ditampilkan pada Tabel 1 .

Tabel 2. menujukkan bahwa variabel pendidikan ibu dan paritas tidak termasuk kedalam variabel confounding berdasarkan hasil statistik analisis crosstabs dengan uji chi square untuk pendidikan ibu diperoleh nilai $p$ value $=0.165$, dan paritas diperoleh nilai $p$ value $=1.000$. Variabel confounding pendidikan ibu dan paritas tidak berhubungan terhadap kejadian BBLR, uji statistik dengan nilai $p>0.05$

Tabel 3. menunjukkan hasil analisis bivariat, variabel terbukti sebagai faktor risiko terhadap kejadian BBLR adalah status gizi kurang $(p=0.004 ; \mathrm{OR}=3.188$; $95 \% \mathrm{CI}=1.421-7.151)$, adanya penyakit kehamilan $(p=0.006 ; \mathrm{O} R=2.589$; $95 \% \mathrm{CI}=1.299-5.148)$, Adanya anggota keluarga merokok dalam rumah $(p=0.020$; $\mathrm{OR}=2.353 ; 95 \% \mathrm{CI}=1.139-4.861)$, dan status sosial ekonomi ( $\mathrm{p}=0.025$; $\mathrm{OR}=2.199$; $95 \% \mathrm{CI}=1.101-4.394$

Tabel 4. menunjukkan hasil analisis multivariat regresi logistik, variabel terbukti sebagai faktor risiko kejadian BBLR status gizi kurang, dan adanya penyakit kehamilan.

Tabel 1. Distribusi Karakteristik Responden Menurut Usia ibu, Pendidikan Ibu, Pekerjaan Ibu, Usia Kehamilan dan Jenis Kelamin Bayi

\begin{tabular}{|c|c|c|c|c|c|}
\hline \multirow{3}{*}{ No. } & \multirow{3}{*}{$\begin{array}{l}\text { Karakteristik } \\
\text { Responden }\end{array}$} & \multicolumn{4}{|c|}{ Status BBLR } \\
\hline & & \multicolumn{2}{|c|}{ Kasus } & \multicolumn{2}{|c|}{ Kontrol } \\
\hline & & $\mathrm{n}$ & $(\%)$ & $\mathrm{n}$ & $(\%)$ \\
\hline \multirow[t]{11}{*}{1.} & $\begin{array}{l}\text { Usia ibu saat melahirkan } \\
\text { anak terakhir }\end{array}$ & & & & \\
\hline & 12-15 tahun & 1 & 1,4 & 0 & 0 \\
\hline & 16-19 tahun & 9 & 13,1 & 9 & 13,1 \\
\hline & 20-23 tahun & 13 & 18,8 & 12 & 17,4 \\
\hline & 24-27 tahun & 21 & 30,4 & 16 & 23,1 \\
\hline & 28-31 tahun & 15 & 21,7 & 9 & 13,1 \\
\hline & 32-35 tahun & 4 & 5,8 & 9 & 13,1 \\
\hline & 36-39 tahun & 3 & 4,4 & 8 & 11,6 \\
\hline & 40-43 tahun & 3 & 4,4 & 5 & 7,2 \\
\hline & 44-47 tahun & 0 & 0 & 1 & 1,4 \\
\hline & Total & 69 & 100.0 & 69 & 100.0 \\
\hline
\end{tabular}




\begin{tabular}{|c|c|c|c|c|c|}
\hline \multirow{3}{*}{ No. } & \multirow{3}{*}{$\begin{array}{c}\text { Karakteristik } \\
\text { Responden }\end{array}$} & \multicolumn{4}{|c|}{ Status BBLR } \\
\hline & & \multicolumn{2}{|c|}{ Kasus } & \multicolumn{2}{|c|}{ Kontrol } \\
\hline & & $\mathrm{n}$ & $(\%)$ & $\mathrm{n}$ & $(\%)$ \\
\hline \multirow[t]{8}{*}{2.} & Tingkat pendidikan ibu & & & & \\
\hline & Tidak Sekolah & 0 & 0.0 & 1 & 1.4 \\
\hline & Sekolah Dasar & 20 & 29.0 & 24 & 34.8 \\
\hline & Sekolah Menengah Pertama & 17 & 24.6 & 20 & 29.1 \\
\hline & Sekolah Menengah Atas & 24 & 34.8 & 18 & 26.1 \\
\hline & Diploma & 1 & 1.4 & 3 & 4.3 \\
\hline & Perguruan Tinggi & 7 & 10.1 & 3 & 4.3 \\
\hline & Total & 69 & 100.0 & 69 & 100.0 \\
\hline \multirow[t]{10}{*}{3.} & Pekerjaan ibu & & & & \\
\hline & Ibu Rumah Tangga & 57 & 82.6 & 64 & 92.8 \\
\hline & Buruh & 0 & 0.0 & 0 & 0.0 \\
\hline & Petani & 0 & 0.0 & 0 & 0.0 \\
\hline & Nelayan & 0 & 0.0 & 0 & 0.0 \\
\hline & Pegawai Negeri Sipil & 0 & 0.0 & 0 & 0.0 \\
\hline & Pegawa Swasta & 6 & 8.7 & 2 & 2.9 \\
\hline & Wiraswasta & 1 & & 3 & 4.3 \\
\hline & Lain-lain & 5 & 7.2 & 0 & 0.0 \\
\hline & Total & 69 & 100.0 & 69 & 100.0 \\
\hline \multirow[t]{4}{*}{4.} & Usia kehamilan ibu & & & & \\
\hline & Prematur ( $<37$ minggu) & 14 & 20.3 & 2 & 2.9 \\
\hline & Cukup bulan (37-41 minggu) & 55 & 79.7 & 67 & 97.1 \\
\hline & Total & 69 & 100.0 & 69 & 100.0 \\
\hline \multirow[t]{4}{*}{5.} & Jenis Kelamin Bayi & & & & \\
\hline & Laki-laki & 35 & 50.7 & 35 & 50.7 \\
\hline & Perempuan & 34 & 49.3 & 34 & 49.3 \\
\hline & Total & 69 & 100.0 & 69 & 100.0 \\
\hline
\end{tabular}

Tabel 2. Analisis bivariat variabel confounding

\begin{tabular}{|c|c|c|c|c|c|c|}
\hline \multirow{2}{*}{ Variabel } & \multirow{2}{*}{ Kategori } & \multicolumn{2}{|c|}{ Kasus } & \multicolumn{2}{|c|}{ Kontrol } & \multirow{2}{*}{$\mathrm{p}$} \\
\hline & & $\mathrm{n}$ & $\%$ & $\mathrm{n}$ & $\%$ & \\
\hline \multirow[t]{2}{*}{ Pendidikan ibu } & Rendah & 37 & 53.6 & 45 & 65.2 & \multirow{2}{*}{0.165} \\
\hline & Tinggi & 32 & 46.4 & 24 & 34.8 & \\
\hline \multirow[t]{2}{*}{ Paritas } & Berisiko & 38 & 55.1 & 38 & 55.1 & \multirow{2}{*}{1.000} \\
\hline & Tidak berisiko & 31 & 44.9 & 31 & 44.9 & \\
\hline
\end{tabular}

Tabel 3. Analisis bivariat variabel confounding

\begin{tabular}{|c|c|c|c|c|c|c|c|c|}
\hline \multirow{2}{*}{ No. } & \multirow{2}{*}{ Variabel } & \multicolumn{2}{|c|}{ Kasus } & \multicolumn{2}{|c|}{ Kontrol } & \multirow{2}{*}{ OR } & \multirow{2}{*}{$95 \% \mathrm{CI}$} & \multirow{2}{*}{$\mathrm{p}$} \\
\hline & & $\mathrm{n}$ & $\%$ & $\mathrm{n}$ & $\%$ & & & \\
\hline \multicolumn{9}{|c|}{ 1. Usia ibu } \\
\hline & $<20$ tahun & 10 & 14.5 & 9 & 13.00 & 0.964 & $0.361-2.578$ & 0.942 \\
\hline & $>35$ tahun & 6 & 8.7 & 14 & 20.3 & 0.372 & $0.132-1.047$ & 0.055 \\
\hline & 20-35 tahun & 53 & 76.8 & 46 & 66.7 & & Pembanding & \\
\hline
\end{tabular}




\begin{tabular}{|c|c|c|c|c|c|c|c|c|}
\hline \multirow{2}{*}{ No. } & \multirow{2}{*}{ Variabel } & \multicolumn{2}{|c|}{ Kasus } & \multicolumn{2}{|c|}{ Kontrol } & \multirow{2}{*}{ OR } & \multirow{2}{*}{$95 \% \mathrm{CI}$} & \multirow{2}{*}{$\mathrm{p}$} \\
\hline & & $\mathrm{n}$ & $\%$ & $\mathrm{n}$ & $\%$ & & & \\
\hline \multirow[t]{3}{*}{2.} & Status gizi & & & & & & & \\
\hline & Kurang & 58 & 84.1 & 43 & 62.3 & 3.188 & $1.421-7.151$ & 0.004 \\
\hline & Baik & 11 & 15.9 & 26 & 37.7 & & & \\
\hline \multirow[t]{3}{*}{3.} & Adanya penyakit kehamilan & & & & & & & \\
\hline & $\mathrm{Ya}$ & 45 & 65.2 & 29 & 42.0 & 2.586 & $1.299-5.148$ & 0.006 \\
\hline & Tidak & 24 & 34.8 & 40 & 58.0 & & & \\
\hline \multirow[t]{6}{*}{4.} & Jarak kehamilan & & & & & & & \\
\hline & Berisiko : jarak & 5 & 7.2 & 9 & 13.0 & 0.521 & $0.165-1.643$ & 0.259 \\
\hline & kehamilan $<2$ tahun & & & & & & & \\
\hline & Tidak berisiko & 64 & 92.8 & 60 & 87.0 & & & \\
\hline & jarak kehamilan 0 dan & & & & & & & \\
\hline & $\geq 2$ tahun & & & & & & & \\
\hline
\end{tabular}

5. Adanya anggota keluarga

merokok dalam rumah

\begin{tabular}{llllllll} 
Berisiko & 52 & 75.4 & 39 & 56.5 & 2.353 & $1.139-4.861$ & 0.020 \\
Tidak berisiko & 17 & 24.6 & 30 & 43.5 & & & \\
\hline
\end{tabular}

6. Adanya budaya pantangan

makanan tertentu:

\section{Cumi}

\begin{tabular}{llllllll} 
Ya & 14 & 20.3 & 10 & 14.5 & 1.502 & $0.616-3.660$ & 0.369 \\
Tidak & 55 & 79.7 & 59 & 85.5 & & & \\
\hline
\end{tabular}

\begin{tabular}{|c|c|c|c|c|c|c|c|c|}
\hline \multicolumn{9}{|c|}{ Udang } \\
\hline & $\mathrm{Ya}$ & 14 & 20.3 & 7 & 10.1 & \multirow[t]{2}{*}{2.255} & \multirow[t]{2}{*}{$0.849-5.991$} & \multirow[t]{2}{*}{0.097} \\
\hline & Tidak & 55 & 79.7 & 62 & 89.9 & & & \\
\hline \multicolumn{9}{|c|}{ Kepiting } \\
\hline & $\mathrm{Ya}$ & 11 & 15.9 & 10 & 14.5 & \multirow[t]{2}{*}{1.119} & \multirow[t]{2}{*}{$0.442-2.836$} & \multirow[t]{2}{*}{0.813} \\
\hline & Tidak & 58 & 84.1 & 59 & 85.5 & & & \\
\hline & \multicolumn{8}{|l|}{ Ikan pari } \\
\hline & $\mathrm{Ya}$ & 7 & 10.1 & 5 & 7.2 & \multirow[t]{2}{*}{1.445} & \multirow[t]{2}{*}{$0.435-4.796$} & \multirow[t]{2}{*}{0.546} \\
\hline & Tidak & 62 & 89.9 & 64 & 92.8 & & & \\
\hline & \multicolumn{8}{|l|}{ Daun Kelor } \\
\hline & $\mathrm{Ya}$ & 4 & 5.8 & 3 & 4.3 & \multirow[t]{2}{*}{1.354} & \multirow[t]{2}{*}{$0.292-6.288$} & \multirow[t]{2}{*}{0.698} \\
\hline & Tidak & 65 & 94.2 & 66 & 95.7 & & & \\
\hline & \multicolumn{8}{|l|}{ Durian } \\
\hline & Ya & 5 & 7.2 & 5 & 7.2 & \multirow[t]{2}{*}{1.000} & \multirow[t]{2}{*}{$0.276-3.622$} & \multirow[t]{2}{*}{1.000} \\
\hline & Tidak & 64 & 92.8 & 64 & 92.8 & & & \\
\hline & \multicolumn{8}{|l|}{ Nanas } \\
\hline & Ya & 12 & 17.4 & 10 & 14.5 & \multirow[t]{2}{*}{1.242} & \multirow[t]{2}{*}{$0.498-3.100$} & \multirow[t]{2}{*}{0.642} \\
\hline & Tidak & 57 & 82.6 & 59 & 85.5 & & & \\
\hline \multirow[t]{4}{*}{7.} & Status ANC & & & & & \multirow{4}{*}{1.000} & \multirow{4}{*}{$0.511-1.956$} & \multirow{4}{*}{1.000} \\
\hline & Tidak lengkap : & 38 & 55.1 & 38 & 55.1 & & & \\
\hline & $\mathrm{ANC}<4 \mathrm{x}$ & & & & & & & \\
\hline & Lengkap : $\geq 4 \mathrm{x}$ & 31 & 44.9 & 31 & 44.9 & & & \\
\hline
\end{tabular}




\begin{tabular}{ccccccccc}
\hline \multirow{2}{*}{ No. } & \multirow{2}{*}{ Variabel } & \multicolumn{2}{c}{ Kasus } & \multicolumn{2}{c}{ Kontrol } & \multirow{2}{*}{ OR } & \multirow{2}{*}{$95 \% \mathrm{CI}$} & $\mathrm{p}$ \\
\cline { 3 - 5 } & & $\mathrm{n}$ & $\%$ & $\mathrm{n}$ & $\%$ & & & \\
\hline 8. & Status sosial ekonomi & & & & & & & \\
& Rendah & 47 & 68.1 & 34 & 49.3 & 2.199 & $1.101-4.394$ & 0.025 \\
& Tinggi & 22 & 31.9 & 35 & 50.7 & & & \\
\hline
\end{tabular}

\section{Pembahasan}

\section{Variabel yang Terbukti Sebagai Faktor Risiko Kejadian BBLR}

\section{Status Gizi}

Hasil analisis multivariat menunjukkan bahwa status gizi kurang memiliki risiko 4.690 kali lebih besar untuk melahirkan BBLR dibanding dengan status gizi baik Hasil ini sejalan dengan penelitian Reza (2014) menunjukkan bahwa LILA $<23.5 \mathrm{~cm}$ merupakan faktor risiko kejadian BBLR $(\mathrm{OR}=3.678 ; 95 \%=1.125-12.027) .18)$ Penelitian Mumbare et al. (2012) menunjukkan bahwa berat badan selama kehamilan merupakan faktor risiko terhadap kejadian BBLR $(\mathrm{OR}=4.82$; CI95\% $=2.54$ 9.15). ${ }^{19}$

\section{Adanya Penyakit Kehamilan}

Variabel adanya penyakit kehamilan (anemia, pre eklampsi/aklampsi, hipertensi, hiperemesis gravidarum) yang dikategorikan sebagai berisiko dalam penelitian ini yaitu jika ada penyakit kehamilan. Hasil analisis multivariat menunjukkan adanya penyakit kehamilan memiliki risiko sebesar 3.697 kali lebih besar untuk melahirkan BBLR dibanding dengan tidak adanya penyakit kehamilan. Tazkiah (2013), menyatakan anemia berisiko melahirkan BBLR $(\mathrm{OR}=$ $2.577 ; 95 \mathrm{CI} \%=1.156-5.742) .{ }^{17}$ Purwanto et al (2016) menunjukkan bahwa hipertensi berisiko terhadap kejadian BBLR $(\mathrm{OR}=2.753 ; 95 \mathrm{CI} \%=1.040-7.292) .{ }^{20}$ Xaverius et al (2016) menunjukkan bahwa hipertensi dalam kehamilan berisiko terhadap kejadian BBLR (OR=4.27; $95 \% \mathrm{CI}=3.81-4.78) .{ }^{21} \mathrm{Subekti} \mathrm{R}$, menunjukkan bahwa hipermesis gravidarum merupakan faktor risiko terhadap kejadian
BBLR (OR=1.96; CI95\%=1.061-3.620).22 Magfirah (2013) menunjukkan bahwa hiperemesis gravidarum merupakan faktor risiko terhadap kejadian $\mathrm{BBLR}(\mathrm{OR}=3.63$; $95 \% \mathrm{CI}=1.5-9.0)$. $^{23}$

Hipermesis gravidarum dapat menyebabkan cadangan karbohidrat habis dipakai untuk keperluan energi, sehingga pembakaran tubuh beralih pada cadangan lemak dan protein. tidak sedikit ibu hamil yang masih mengalami mual muntah sampai trimester ketiga. Muntah yang berlebihan menyebabkan cairan tubuh makin berkurang, sehingga darah menjadi kental (hemokonsentrasi) yang dapat memperlambat peredaran darah yang berarti komsumsi $\mathrm{O}_{2}$ dan makanan ke jaringan berkurang yang dapat menambah beratnya keadaan janin dan wanita hamil. ${ }^{14,27}$

\section{Variabel yang Tidak Terbukti Bukan sebagai Faktor Risiko Kejadian BBLR}

\section{Usia ibu $<20$ tahun atau $>35$ tahun}

Hasil analisis bivariat menunjukkan bahwa usia ibu $<20$ tahun $(\mathrm{OR}=0.964$; $95 \% \mathrm{CI}=0.361-2.578)$ terbukti bukan merupakan faktor risiko terhadap kejadian BBLR. Hasil penelitian ini sejalan dengan penelitian Nasreen (2010), bahwa usia ibu < 20 tahun bukan merupakan faktor risiko kejadian BBLR $(\mathrm{OR}=1.14 ; 95 \% \mathrm{CI}=0.69$ 1.88). ${ }^{29}$ Jayant et al (2011) menunjukkan bahwa usia ibu $<20$ tahun atau $>35$ tahun bukan merupakan faktor risiko kejadian BBLR $(\mathrm{OR}=1.740 ; 95 \% \mathrm{CI}=0.95-3.91){ }^{30}$ Brown (2008) menunjukkan bahwa usia ibu $<20$ tahun merupakan faktor risiko kejadian BBLR $(\mathrm{OR}=12.79 ; 95 \% \mathrm{CI}=12.21-13.39) .{ }^{31}$ Salawati (2012) menunjukkan bahwa usia $\mathrm{ibu}<20$ tahun atau $>35$ tahun merupakan faktor risiko kejadian BBLR $(\mathrm{OR}=10.7$ : $\mathrm{CI} 95 \%=3.14-36.7){ }^{32}$ 
Hasil analisis multivariat menunjukkan bahwa usia ibu $>35$ tahun $(\mathrm{OR}=0.333$; $95 \% \mathrm{CI}=0.103-1.072)$ terbukti bukan merupakan faktor risiko terhadap kejadian BBLR. Hal tersebut disebabkan oleh variabel lainya yang memiliki pengaruh lebih kuat terhadap kejadian BBLR. Hasil penelitian ini sejalan dengan penelitian yang dilakukan oleh Ghosh (2013) bahwa usia ibu > 35 tahun bukan merupakan faktor risiko kejadian BBLR $(\mathrm{OR}=0.88 ; 95 \% \mathrm{CI}=0.44-1.54) .33$ Hasil penelitian Angraini (2014) menunjukkan bahwa usia ibu $<20$ tahun atau $>35$ tahun bukan merupakan faktor risiko kejadian BBLR $(\mathrm{OR}=3.193 ; 95 \% \mathrm{CI}=0.796$ 12.808). ${ }^{34}$ Momeni et al (2017) mengatakan bahwa usia ibu $>35$ tahun merupakan faktor risiko kejadian BBLR ( $\mathrm{OR}=1.21$; 95\% CI=1.08-1.36). ${ }^{35}$ Jaya Ningsih (2009) menunjukkan bahwa usia ibu $<20$ tahun atau $>35$ tahun mempunyai risiko 3,78 kali lebih besar untuk melahirkan BBLR dibanding dengan umur ibu 20-35 tahun. ${ }^{36}$ Usia ibu $>35$ tahun lebih siap dalam menjaga kehamilan, keterampilan ibu untuk melaksanakan perawatan diri dan bayinya, serta faktor psikologis ibu yang sudah stabil.

\section{Jarak Kehamilan}

Hasil analisis bivariat menunjukkan bahwa jarak kehamilan berisiko $(\mathrm{OR}=0.521$; $95 \% \mathrm{CI}=0.165-1.643)$ terbukti bukan merupakan faktor risiko terhadap kejadian BBLR. Penelitian ini sejalan dengan penelitian yang dilakukan oleh Ismi (2011) bahwa jarak kehamilan bukan merupakan faktor risiko terhadap kejadian BBLR $(\mathrm{OR}=1.645 ; 95 \% \mathrm{CI}=0.207-13.076) .{ }^{32}$ Deshphande et al, (2011) menunjukkan bahwa jarak kehamilan $<2$ tahun mempunyai risiko 1,75 kali lebih besar untuk melahirkan BBLR dibanding dengan jarak kehamilan $\geq 2$ tahun. ${ }^{30}$

Jarak kehamilan $<2$ tahun bukan merupakan faktor risiko terhadap kejadian BBLR disebabkan karena sebagian besar responden memiliki jarak kehamilan tidak berisiko ( $\geq 2$ tahun), baik kelompok kasus $(92.8 \%)$ maupun kelompok kontrol (87.0\%). Jarak antar kelahiran $>2$ tahun akan memberi kesempatan kepada ibu untuk pulih secara fisik dan emosi sebelum mengalami kehamilan lagi. ${ }^{38}$

\section{Adanya Anggota Keluarga Merokok dalam Rumah}

Hasil analisis bivariat menunjukkan bahwa adanya anggota keluarga merokok dalam rumah $(\mathrm{OR}=2.353$; 95\% $\mathrm{CI}=1.139$ 4.861) terbukti merupakan faktor risiko terhadap kejadian BBLR. Proporsi adanya anggota keluarga merokok dalam rumah pada kelompok kasus (75.4\%) lebih besar dibandingkan pada kelompok kontrol $(56.5 \%)$. Setelah dilakukan analisis multivariat, variabel adanya anggota keluarga merokok dalam rumah $(\mathrm{OR}=2.353$; $95 \% \mathrm{CI}=1.139-4.861)$ terbukti bukan merupakan faktor risiko terhadap kejadian BBLR. Hal tersebut disebabkan oleh variabel lainya yang memiliki pengaruh lebih kuat terhadap kejadian BBLR. Mahdalena et al (2014) menunjukkan bahwa tidak ada pengaruh rokok terhadap kejadian BBLR dari ibu hamil perokok aktif, perokok pasif maupun tidak perokok $(p=0.78){ }^{39}$ Amalia (2011) menunjukkan bahwa ibu yang terpapar asap rokok merupakan faktor risiko terhadap kejadian BBLR $(\mathrm{OR}=5,385$; $\mathrm{CI}$ $(95 \%)=2,275-12,744) .40$ Noriani et al (2015) menunjukkan bahwa paparan asap rokok dalam rumah meningkatkan risiko terjadinya prematur $(\mathrm{OR}=3,647 ; 95 \% \mathrm{CI}$ : $1,683-9,903){ }^{41}$

\section{Adanya Budaya Pantangan Makanan Tertentu}

Adanya pantangan makanan tertentu yang dikategorikan dalam penelitian ini adalah adanya pantangan makanan cumicumi, udang, kepiting, ikan pari, daun kelor, durian, dan nanas. Hasil analisis bivariat menunjukkan bahwa adanya budaya pantangan makanan cumi-cumi $(\mathrm{OR}=1.502$; $95 \% \mathrm{CI}=0.616-3.660)$ terbukti bukan merupakan faktor risiko terhadap kejadian BBLR. Adanya budaya pantangan makanan cumi-cumi bukan merupakan faktor risiko terhadap kejadian BBLR disebabkan karena proporsi responden pantang makan cumicumi $(20.3 \%)$ pada kelompok kasus hampir 
sebanding pada kelompok kontrol (14.5\%).

Hasil analisis bivariat menunjukkan bahwa adanya budaya pantangan makanan ikan pari $(\mathrm{OR}=1.445$; OR95\% $\mathrm{CI}=0.435$ 4.796) terbukti bukan merupakan faktor risiko terhadap kejadian BBLR. Adanya budaya pantangan makanan ikan pari bukan merupakan faktor risiko terhadap kejadian BBLR disebabkan karena proporsi responden pantang makan ikan pari (10.1\%) pada kelompok kasus hampir sebanding pada kelompok kontrol (7.2\%).

Hasil analisis bivariat menunjukkan bahwa adanya budaya pantangan makanan durian $(\mathrm{OR}=1.000 ; \mathrm{OR} 95 \% \mathrm{CI}=0.276-3.622)$ terbukti bukan merupakan faktor risiko terhadap kejadian BBLR. Adanya budaya pantangan makanan durian bukan merupakan faktor risiko terhadap kejadian BBLR disebabkan karena proporsi responden pantang makan durian $(7.2 \%)$ pada kelompok kasus sebanding pada kelompok kontrol (7.2\%). Hasil analisis bivariat menunjukkan bahwa adanya budaya pantangan makanan nanas $(\mathrm{OR}=1.242$; OR95\%CI $=0.498-3.100)$ terbukti bukan merupakan faktor risiko terhadap kejadian BBLR. Adanya budaya pantangan makanan nanas bukan merupakan faktor risiko terhadap kejadian BBLR disebabkan karena proporsi responden pantang makan nanas $(17.4 \%)$ pada kelompok kasus hampir sebanding pada kelompok kontrol (14.5\%).

\section{Status ANC}

Hasil analisis bivariat menunjukkan bahwa status ANC tidak lengkap $(\mathrm{OR}=1.00$; $95 \% \mathrm{CI}=0.511-1.956)$ terbukti bukan merupakan faktor risiko terhadap kejadian BBLR. Yuliani et al (2015) menunjukkan bahwa status ANC bukan merupakan faktor risiko terhadap kejadian BBLR (OR=1.6; $95 \% \mathrm{CI}=0.60-2.32) .{ }^{44}$ Penelitian Marlenywati (2015) menunjukkan bahwa status ANC $<4 \mathrm{x}$ mempunyai risiko 3.345 kali lebih besar untuk melahirkan BBLR dibanding dengan status ANC $>4 \times .45$ Setelah dilakukan analisis multivariat, variabel status sosial ekonomi rendah $(\mathrm{OR}=2.171 ; 95 \% \mathrm{CI}=0.955-4.937)$ terbukti bukan merupakan faktor risiko terhadap kejadian BBLR. Hal tersebut disebabkan oleh variabel lainya yang memiliki pengaruh lebih kuat terhadap kejadian BBLR. Penelitian ini sejalan dengan penelitian Angraini (2014) menunjukkan bahwa penghasilan rendah bukan merupakan faktor risiko terhadap kejadian BBLR $(\mathrm{OR}=1.000$; $95 \% \mathrm{CI}=0.414-2.413)^{46}$

\section{Kesimpulan}

Faktor ibu yang terbukti sebagai faktor risiko kejadian BBLR adalah status gizi kurang, dan adanya penyakit kehamilan. Probabilitas untuk menyebabkan kejadian BBLR jika terdapat 2 faktor risiko tersebut secara bersamaaa adalah $68.87 \%$. Faktor ibu dan faktor lingkungan yang terbukti bukan sebagai faktor risiko kejadian.

\section{Ucapan Terimakasih}

Terimakasih kasih kepada pihak Puskesmas Antang, Puskesmas Tamangapa, Puskesmas KalukuBodoa, Puskesmas Minasa Upa, Puskesmas Rappokalling, dan Puskesmas Pattingallong yang memberikan banyak informasi dan membantu penulis selama berada dalam lapangan.

\section{Daftar Pustaka}

1. WHO. 2014. Global Nutrition Target 2025: Low Birth Weight Policy Brief. Geneva.

2. WHO. 2011. Optimal Feeding Of Low Birthweigh Infants in Low-And Middle Income Countries. Geneva: World Health Organization.pp.5

3. Mochtar A. 2008. Persalinan Preterm. In: Rachimhadhi T, Wiknjosastro GH,editors. Ilmu Kebidanan Sarwono Prawirohardjo. 4th ed. Jakarta: Bina Pustaka Sarwono Prawirohardjo.pp. 667-679.

4. Amiruddin R, Hasmi. 2014. Determinan Kesehatan Ibu dan Anak. 1st ed. Jakarta: CV. Trans Info Media.pp.31-181

5. WHO. 2011. Optimal Feeding of Low Birth-Weight Infants in Low-and Middle-Income Countries. Geneva: WHO.pp.5 
6. United Nations Children's Fund and World Health Organization. 2004. Low Birthweight: Country,Regional and Global Estimates.pp.1-31.

7. WHO. 2013. Maternal, Newborn, Child and Adolescent Health Care of the Preterm and/ or Low-Birth-Weight Newborn.

8. Kemenkes RI. 2015. Profil Kesehatan Indonesia Tahun 2014. Jakarta: Kementerian Kesehatan Republik Indonesia; 87.pp.106-107.

9. Kemenkes RI. Riset Kesehatan Dasar 2013. Jakarta: Badan Penelitian dan Pengembangan Kesehatan Kementerian Kesehatan RI.pp.182-183.

10. Riset Kesehatan Dasar dalam Angka Provinsi Sulawesi Selatan Tahun 2013. Jakarta: Badan Penelitian dan Pengembangan Kesehatan.pp.1-425

11. Dinkes Provinsi Sulawesi Selatan. 2015. Profil Kesehatan Sulawesi Selatan 2014. Makassar: Dinas Kesehatan Provinsi Sulawesi Selatan.pp. 58-59.

12. Dinkes Kota Makassar. 2015. Profil Kesehatan Kota Makassar Tahun 2014. Makassar: Dinas Kesehatan Kota Makassar.pp.35-36.

13. Pramono MS, Paramita A. 2015. Pattern of Occurrence and Determinants of Baby With Low Birth Weight in Indonesia 2013 . Bul Penelit Sist Kes ehat;18(1).

14. Manuaba AC, Manuaba IBG, Manuaba B G . 2010. Ilmu Kebidanan, Penyakit Kandungan, dan KB untuk Pendidikan Bidan. 2nd ed. Jakarta: EGC.pp.227436.

15. Krisnadi SR. 2009. Faktor Risiko Persalinan Prematur. In: Krisnadi SR, Effendi JS, Pribadi A, editors. Prematuritas. 1st ed. Bandung: PT. Refika Aditama.pp.43-65.

16. Yongky, Hardinsyah, Gulardi, Marham. 2010.Status Gizi Awal Kehamilan dan Pertambahan Berat Badan Ibu Hamil Kaitanya dengan BBLR. J Gizi dan Pangan;4(1).pp.8-12. Tazkiah M, Wahyuni CU, Martini S.

17. 2013.Determinan Epidemiologi Kejadian BBLR pada Daerah Endemis
Malaria di Kabupaten Banjar Provinsi Kalimantan Selatan. Jurnal Berkala Epidemiologi;1(2).pp.266-276.

18. Reza Chaerul, Puspitasari N . 2014. Determinants of Low-Birth-WeightNeonates. Jurnal Biometrika dan Kependudukan;3(2).pp.96-106.

19. Mumbare S, Maindarkar G, Darade R, Yenge S, Tolani MK,Patole K. 2012. Maternal Risk Factors Associated with Term Low Birth Weight Neonates A Matched-Pair Case Control Study. Indian Pediatr Januari16;49.pp.25-28.

20. Dewi PA, Umbul WC. 2012. Hubungan Antara Umur Kehamilan, Kehamilan Ganda, Hipertensi dan Anemia dengan Kejadian Bayi Berat Lahir Rendah (BBLR).Jurnal Berkala Epidemiol;4(3).pp.349-359.

21. Xaverius P, Alman C, Holtz L, Yarber L. 2016. Risk Factors Associated with Very Low Birth Weight in a Large Urban Area,Stratified by Adequacy of Prenatal Care. Maternal and Child Health Journal;20(3).pp.623-629.

22. Subekti R.2014. Analisis Faktor Risiko Kejadian Berat Badan Lahir Rendah di Kabupaten Banjarnegara. Semarang: Universitas Diponegoro.

23. Magfirah, Anita. 2013. Riwayat Hiper mesis Gravidarum Terhadap Risiko Kejadian Bayi Berat Lahir Rendah di Banda Aceh. Idea Nursing Journal;4(2): pp.30-35.

24. Mahayana SAS, Chundrayetti E, Yulistini. 2015. Faktor Risiko yang Berpengaruh Terhadap Kejadian Badan Lahir Rendah di RSUP Dr. M. Djamil Padang. Jurnal Kesehatan Masyarakat Andalas ;4(3).pp.664-673.

25. Safitri N. 2015. Anemia pada Masa Kehamilan Sebagai Faktor Risiko Bayi Berat Lahir Rendah. Semarang: Univer sitas Diponegoro.

26. Karima K, Achadi EL. 2012. Status Gizi Ibu dan Berat Badan Lahir Bayi. Jurnal Kesehatan Masyarakat Nasional;7(3).pp.111-119.

27. Rukiyah AY, Yulianti L. 2010. As uhan Kebidanan Patologi Kebidanan. 4th ed. Jakarta: Trans Info Media.pp. 118-173. 
28. Rochjati. 2011. Skrining Antenatal pada Ibu Hamil. 2nd ed. Surabaya: Airlangga University Press. pp.1-177.

29. Nasreen HE, Kabir ZN, Forsell Y, Edhborg M. 2010. LowBirth Weight in Offspring of Women with Depressive and Anxiety Symptoms During Pregnancy: Results from a Population based study in Bangladesh. BMC Public Health:10.pp.515.

30. Jayant D, Phalke, Bangal, Peeyuusha, Sushen B. 2011. Maternal Risk Factors for Low Birth Weight Neonates : a Hospital Based Case-Control Study in Rural Area of Western Maharashtra,. National Journal of Community Medicine;2(3).pp.394-398.

31. Brown JS, Adera T, Masho SW. 2008. Previous Abortion and The Risk of Low Birth Weight and Preterm Births. Journal of Epidemiology and Community Health;62(1).pp.16-22.

32. Salawati L. 2012. Hubungan Usia, Paritas dan Pekerjaan Ibu Hamil dengan Paritas, dan Pekerjaan Ibu Hamil dengan an Bayi Berat Lahir Rendah. Jurnal Kedokteran Syiah Kuala;12(3).

33. pp.138-142.

Ghosh JKC, Wilhelm M, Ritz B. 2013.

Effects of Residential Indoor Air Quality and Household Ventilation on Preterm Birth and Term Low Birth Weight in Los Angeles County, California. American Journal of Public Health;103(4).pp.686-694.

34. Pramono MS, Paramita A. 2015. Pola Kejadian dan Determinan Bayi Dengan Berat Badan Lahir Rendah (BBLR) di Indonesia Tahun 2013. Buletin Peneliti an Sistem Kesehatan;18(1).pp. 1-10.

35. Momeni M, Mina D, Nejad KAJ, Marzieh B, Shohreh F, Zahra M, et al. 2017. Prevalence and Risk Factors of Low Birth Weight in the Southeast of Iran. International Journal of Prevention Medicine;8(12).pp.1-7.

36. Jaya N. 2009. Analisis Faktor Resiko Kejadian Bayi Berat Lahir Rendah di Rumah Sakit Ibu dan Anak Siti Fatimah Kota Makassar. Media Gizi Pangan;VII(1).pp.1-55.

37. Trihardiani. 2011. Risiko Kejadian
Lahir Berat Badan Rendah di Wilayah. Kerja Puskesmas Singkawang Timur dan Utara Kota Singkawang. Universitas Diponegoro.

38. Kemenkes RI.2013. Survei Demografi dan Kesehatan Indonesia 2012. Jakarta: Badan Kependudukan dan Keluarga Berencana Nasional Badan Pusat Statistik Kementerian Kesehatan.pp.22-63

39. Mahdalena, P., Sugian NH. 2014. Pengaruh Rokok Terhadap Berat Badan Bayi Baru Lahir di RSUD Banjarbaru. Jurnal Skala Kesehatan;5(2).pp.2-7.

40. Amalia L.2011. Faktor Risiko Kejadian Berat Lahir Rendah (BBLR) di RSUD dr. MM Dunda Limboto Kabupaten Gorontalo. Jurnal Sainstek; 6(3).pp.249 -260 .

41. Noriani NK, Putra IWGAE, Karmaya. 2015. Paparan Asap Rokok dalam Rumah Terhadap Risiko Peningkatan Kelahiran Bayi Prematur di Kota Denpasar. Journal of Preventive Medicine and Public Health ;3(1).pp.68-73.

42. Nurul HD, Febrianti, Minsarnawati. 2012. Kebiasaan Makan Menjadi Salah Satu Penyebab Kekurangan Energi (KEK) pada Ibu Hamil di Poli Kebidanan RSI dan Lestari Cirendeu Tange rang Selatan. Jurnal Kesehatan Reproduksi;3(3).pp.91-104.

43. Oktriyani, Juffrie M, Astiti D. 2014. Pola Makan dan Pantangan Makan Tidak Berhubungan Dengan Kekurangan Energi Kronis Pada Ibu Hamil. Jurnal Gizi dan Diet Indonesia;2(3). pp.159-69.

44. Yuliani, Putri IWGAE,Windiani IGAT. 2015. Faktor Risiko Kejadian Bayi Berat Lahir Rendah di Rumah Sakit Umum Daerah dr.R.Soedjono Kabupaten Lombok Timur. Journal of Preventive Medicine and Public Health;3(2). pp.167-172.

45. Marlenywati, Hariyadi D, Ichtiyati F. 2015. Faktor-Faktor yang Mempengaruhi Kejadian BBLR di RSUD dr. Soedarso Pontianak. Jurnal Vokasi Kesehatan;1(5).pp.154-160.

46. Anggraini D, Aditiawarman, Utomo B, Suryawan A. 2014. Risk Factors of Low Birth Weight (LBW) Incidence. A Case Control Study.Folia Medica Indonesia; 50(4).pp.270-277. 
Manyeh AK, Kukula V, Odonkor G, Ekey RA, Adjei A, Narh-bana S, et al. 2016. Socioeconomic and Demographic Determinants of Birth Weight in Southern Rural Ghana: Evi dence From Dodowa Health and Demographic Surveillance System. BMC Pregnancy chilbirth;16(160).pp.1-10. 